\title{
PELATIHAN PENGGUNAAN APLIKASI GEOGEBRA PADA PEMBELAJARAN MATERI LINGKARAN DI SMPN 10 KOTA SERANG
}

\author{
Huswatun Hasanah \\ Manajemen Infoematika, Universitas Banten Jaya, Jl Syech Nawawi Albantani Serang, Banten, Indonesia \\ Email: huswatunhasanah2020@gmail.com
}

\begin{abstract}
The aim of this Community Service Program is to train the students of eighth grade at SMP Negeri 10 Kota Serang to be experts in the use of the Geogebra. The application can make it easier for students to draw geometric shapes so that it makes students better understand math, especially The Circle. The methods are (1) Introduction to the Geogebra application, (2) Explanation of the use of the Geogebra application in mathematics learning, especially The Circle, and (3) Simulation of using the Geogebra application on The Circle. With the increased understanding of The Circle concept and students' expertise in using the Geogebra application hoping students can understand the next concept related to the concept studied.
\end{abstract}

Keywords: Training; Math Application; Geogebra; The Circle.

\begin{abstract}
ABSTRAK
Tujuan diadakan kegiatan Pengabdian Kepada Masyarakat ini adalah untuk melatih siswa kelas VIII di SMP Negeri 10 Kota Serang agar ahli dalam penggunaan aplikasi Geogebra. Geogebra dipilih karena dianggap lebih mudah untuk di-install dan dapat secara online. Aplikasi tersebut dapat memudahkan siswa dalam menggambar bentuk geometri sehingga membuat siswa lebih memahami materi matematika, khususnya lingkaran. Metode yang digunakan dalam kegiatan ini adalah (1) Pengenalan program aplikasi Geogebra, (2) Penjelasan penggunaan program aplikasi Geogebra dalam pembelajaran matematika, khususnya materi lingkaran, dan (3) Simulasi penggunaan program aplikasi Geogebra pada materi lingkaran. Hasil dari kegiatan tersebut adalah siswa dapat mengenal dan memahami aplikasi Geogebra dan siap untuk menggunakannya untuk mendalami materi lingkaran.
\end{abstract}

Kata Kunci: Pelatihan; Aplikasi Matematika; Geogebra; Lingkaran.

\section{PENDAHULUAN}

Undang-undang Nomor 20 Tahun 2003 tentang Sistem Pendidikan Nasional mengamanatkan penyelenggaraan pendidikan diharapkan dapat mewujudkan proses berkembangnya kualitas pribadi dan potensi peserta didik sebagai generasi penerus bangsa di masa depan (Nasional, 2003). Hal tersebut merupakan faktor penentu bagi perkembangan negara Indonesia. Seperti yang pernah dibuktikan dalam sejarah bahwa determinasi kemajuan dan kejayaan suatu bangsa di dunia adalah pembangunan di bidang pendidikan. 
Kemajuan teknologi memberikan kontribusi yang signifikan untuk mewujudkan proses berkembangnya kualitas potensi peserta didik. Matematika adalah salah satu ilmu yang berkembang seiring dengan kemajuan teknologi. Menurut Susanah (2018), teknologi di bidang pendidikan digunakan untuk mengembangkan media pembelajaran, seperti halnya di pembelajaran matematika menggunakan media dengan bantuan software-software yang sudah tersedia dan mudah diunduh oleh pengguna. Pemanfaatan teknologi dalam pembelajaran matematika dapat memudahkan guru saat mengajar. Guru tidak membutuhkan waktu lama untuk menggunakan kapur tulis atau spidol dalam menggambar objek bangun ruang. Hal ini juga dapat mengoptimalkan waktu guru dalam menjelaskan materi pelajaran lebih banyak narasi yang harus ditulis atau gambar-gambar geometri yang rumit (Koswara, 2017).

Berdasarkan hasil observasi dan wawancara di SMP Negeri 10 Kota Serang sebagai mitra yang merupakan sekolah dengan jarak yang tidak jauh dari pusat kota. Sekolah tersebut memiliki sarana dan prasarana cukup memadai untuk digunakan dalam materi pelajaran yang berkaitan dengan penggunaan teknologi. Namun, hasil wawancara juga menunjukkan bahwa secara umum guru-guru matematika di sekolah mitra masih cenderung belum mengoptimalkan teknologi khususnya penggunaan software/aplikasi dalam proses pembelajaran. Dengan demikian, dilakukan kegiatan PKM yang berupa penggunaan aplikasi geogebra pada pembelajaran materi lingkaran pada siswa kelas VIII di SMP 10 Kota Serang.

Salah satu aplikasi yang dapat digunakan dalam pembelajaran matematika adalah Geogebra. Rismawati, Hayati \& Khatimah (2020) menyebutkan bahwa geogebra merupakan software dinamis yang menggabungkan geometri, aljabar, dan kalkulus. Sedangkan, menurut Tanzimah (2019) geogebra adalah perangkat lunak matematika yang dinamis, bebas, dan multi-platform yang menggabungkan geometri, aljabar, tabel, grafik, statistik dan kalkulus dalam satu paket yang mudah dan bisa digunakan untuk semua jenjang pendidikan. Makna dari dinamis adalah pengguna dapat menghasilkan aplikasi matematika yang interaktif. Bebas diartikan dapat digunakan dan digandakan dengan cuma-cuma serta termasuk perangkat lunak opensource sehingga setiap orang dapat mengubah atau memperbaiki programnya. Multi-platform berarti Geogebra tersedia untuk segala jenis komputer seperti Windows, Mac OS, Linux dan sebagainya. Semua materi yang memuat konsep tersebut dapat mengunakan Geogebra sebagai media pembelajarannya, tetapi bergantung juga pada kreativitas dan kemampuan guru mengolah materi menjadi lebih menarik menggunakan Geogebra (Nur, 2016).

Hasil wawancara dengan siswa SMP Negeri 10 Kota Serang menyatakan bahwa siswa mengalami kesulitan memahami pelajaran yang berkaitan dengan Geometri. Hal ini disebabkan guru yang kurang fasih dalam penggunaan aplikasi komputer untuk mengajarkan materi geometri kepada siswanya. Padahal, pemilihan dan penggunaan media yang tepat dapat 
membuat siswa tertarik belajar geometri dan pada akhirnya dapat meningkatkan hasil belajar matematikanya.

Peneliti memilih Geogebra dalam kegiatan ini karena fitur-fitur yang ada di dalam aplikasi tersebut sesuai dengan materi yang akan diberikan yaitu lingkaran. Menurut Mahmudi (2010), pemanfaatan program Geogebra memberikan beberapa keuntungan, yaitu:

1. Lukisan-lukisan geometri yang biasanya dihasilkan dengan dengan cepat dan teliti dibandingkan dengan menggunakan pensil, penggaris, atau jangka.

2. Adanya fasilitas animasi dan gerakan-gerakan manipulasi (dragging) pada program Geogebra dapat memberikan pengalaman visual yang lebih jelas kepada siswa dalam memahami konsep geometri.

3. Dapat dimanfaatkan sebagai balikan/evaluasi untuk memastikan bahwa lukisan yang telah dibuat benar.

4. Mempermudah guru/siswa untuk menyelidiki atau menunjukkan sifat-sifat yang berlaku pada suatu objek geometri.

Septian (2017) mengungkapkan beberapa kelebihan geogebra antara lain:

1. Grafik, aljabar dan tabel terhubung dan sangat dinamis.

2. Mudah digunakan namun banyak fitur canggih.

3. Authoring tool (alat pengubah) untuk membuat bahan pembelajaran interaktif sebagai halaman web.

4. Tersedia dalam banyak bahasa untuk jutaan pengguna kami di seluruh dunia.

5. Perangkat lunak open source yang tersedia secara bebas untuk pengguna nonkomersial.

Selain itu, banyak penelitian yang menunjukkan bahwa penggunaan Geogebra dapat membantu siswa dalam pembelajaran. Salah satu penelitian yang dilakukan oleh Agung et al., (2019) dalam mengembangkan perangkat pembelajaran berbasis geogebra pada materi geometri untuk meningkatkan Higher Order Thinking Skills siswa. Penelitian ini mengacu pada model pengembangan Borg and Gall yang telah dimodifikasi dan membuktikan bahwa aplikasi geogebra berhasil meningkatkan kemampuan HOTS siswa. Sama halnya dengan penelitian yang dilakukan oleh Hasanah (2020) dalam pengembangan bahan ajar berbasis STEM dimana unsur teknologinya menggunakan aplikasi Geogebra telah mendapatkan hasil uji coba kelompok besar berupa rata-rata total $68 \%$ dengan kriteria valid secara kuat. Berbagai hal tersebut yang akhirnya mendasari penulis untuk memilih Geogebra sebagai aplikasi dalam kegiatan ini. 


\section{METODE}

Kegiatan yang dilakukan adalah pelatihan penggunaan aplikasi geogebra pada pembelajaran materi lingkaran pada siswa kelas VIII di SMP 10 Kota Serang. Kegiatan ini dilaksanakan pada hari Kamis, tanggal 7 Februari 2019. Peserta merupakan siswa Kelas VIII C di SMP Negeri 10 Kota Serang.

Metode yang digunakan dalam kegiatan Pengabdian Kepada Masyarakat (PKM) ini adalah:

1. Pengenalan program aplikasi Geogebra.

2. Penjelasan penggunaan program aplikasi Geogebra dalam pembelajaran matematika, khususnya materi lingkaran.

3. Simulasi penggunaan program aplikasi Geogebra pada materi lingkaran.

\section{HASIL DAN PEMBAHASAN}

\section{Pengenalan program aplikasi Geogebra.}

Kegiatan diawali dengan pengenalan program aplikasi Geogebra kepada siswa. Geogebra merupakan software yang berisi aplikasi aljabar dan geometri. Aplikasi ini dipilih karena dianggap lebih mudah untuk di-install dan dapat secara online digunakan dengan mengakses situs https://www.geogebra.org/. Selain itu, siswa juga dapat menggunakan secara offline dengan menginstal di laptop/komputer.

Berikut adalah tampilan awal situs Geogebra versi online saat siswa mengakses situs https://www.geogebra.org/. Terdapat banyak menu yang dapat dipilih oleh pengguna. Dari sini, siswa dapat memilih tampilan yang diinginkan berupa 2 Dimensi atau 3 Dimensi untuk lebih memahami materi yang ada di mata pelajaran matematika.

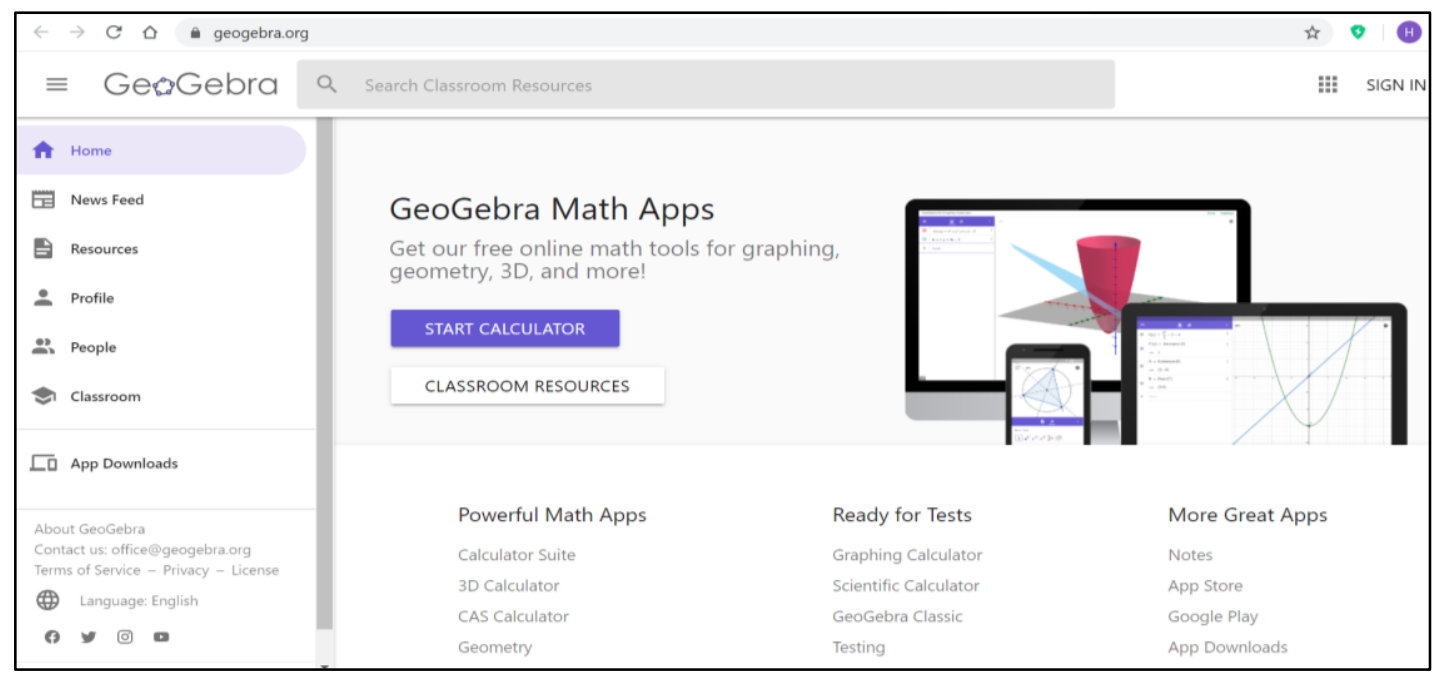

Gambar 1. Tampilan Awal Situs Geogebra versi Online 
Saat menginginkan tampilan 2 Dimensi, siswa dapat memilih menu Calculator Site. Setelah itu, akan muncul tampilan pada Gambar 2. Tampilan 2 Dimensi digunakan untuk membuat gambar-gambar yang mempunyai dua sisi saja dan tidak memiliki ketebalan. Contohnya adalah persegi, persegi panjang, segitiga, dan lingkaran.

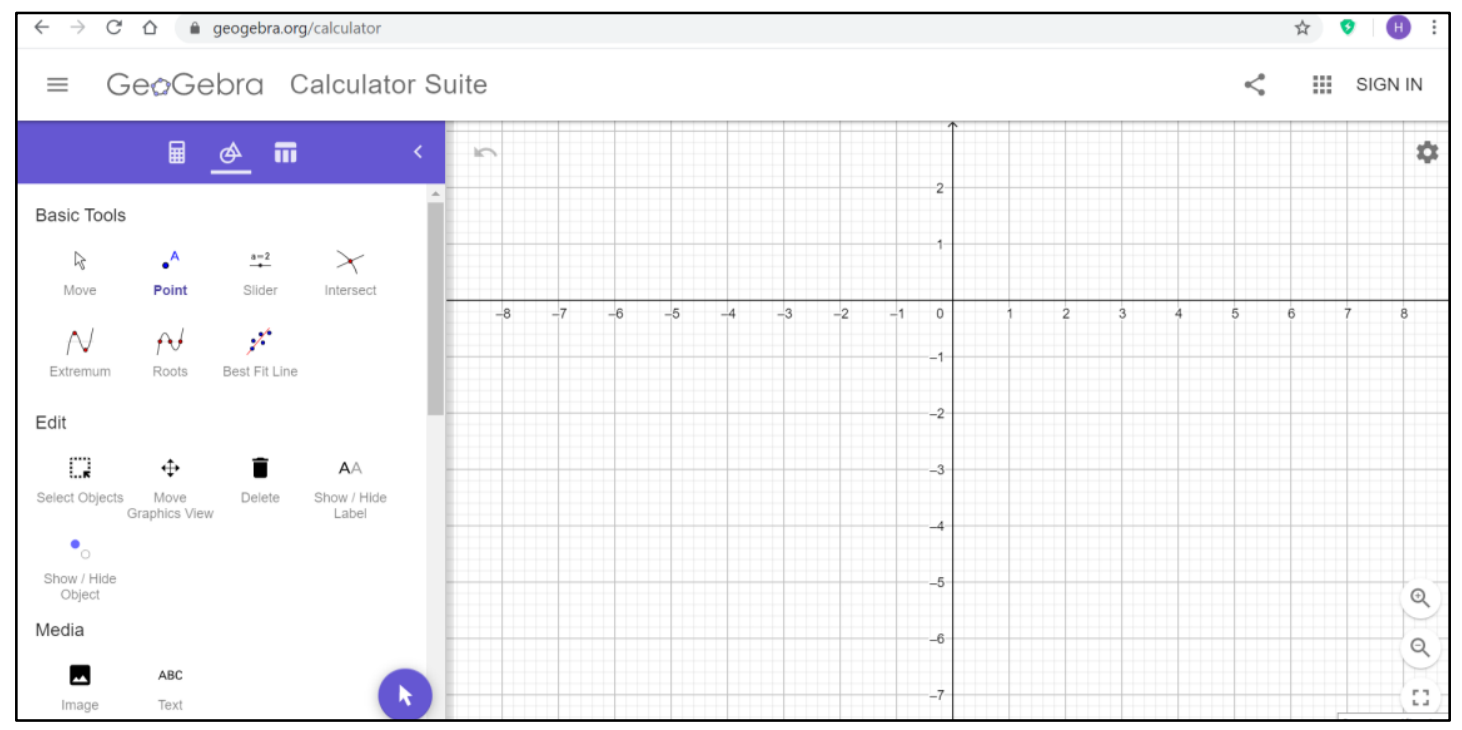

Gambar 2. Tampilan Situs Geogebra 2 Dimensi versi Online

Apabila ingin menampilkan bentuk 3 Dimensi, siswa dapat memilih menu 3D Calculator pada tampilan awal situs Geogebra. Geogebra 3 Dimensi dipilih jika siswa ingin menampilkan bentuk yang sesuai aslinya dimana memiliki unsur panjang, lebar, dan tinggi. Contohnya adalah bangun ruang yang ada di materi matematika, seperti kubus, balok, prisma, limas, kerucut, dan tabung.

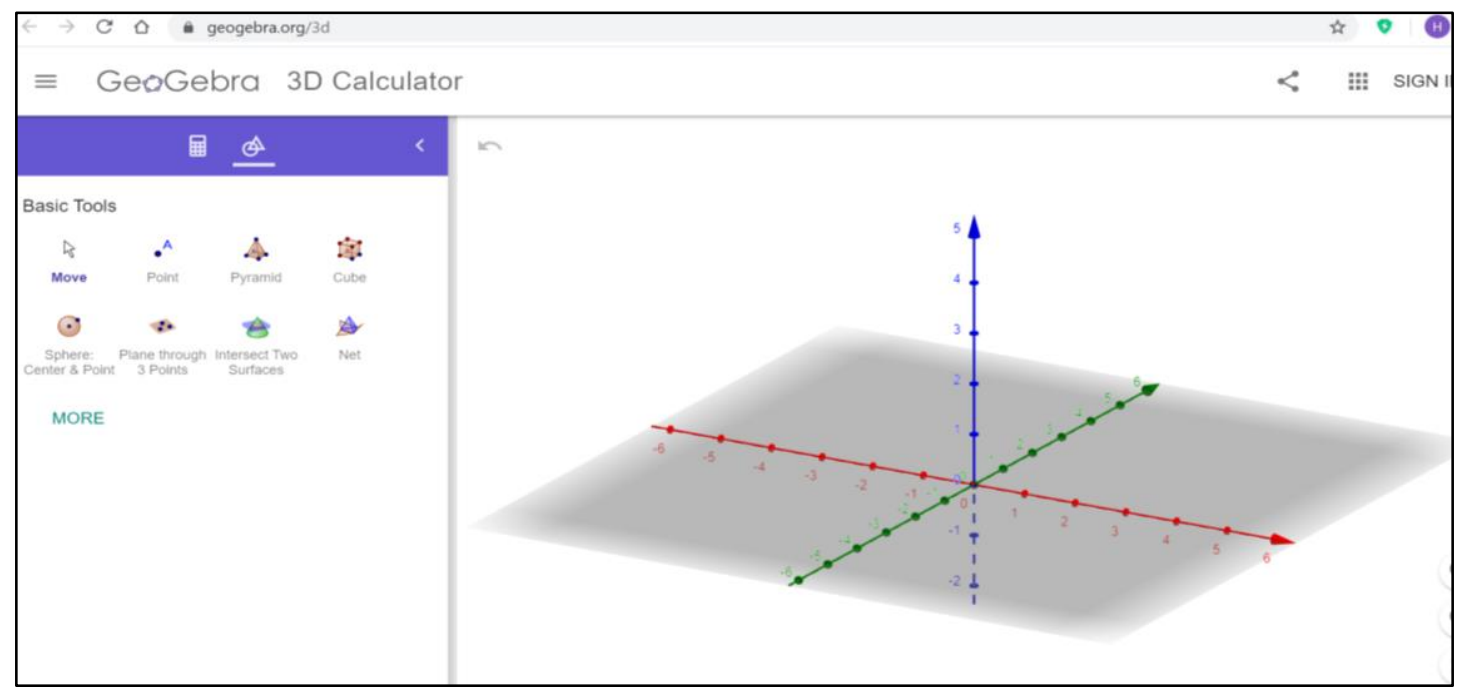

Gambar 3. Tampilan Situs Geogebra 3 Dimensi versi Online 


\section{Penjelasan penggunaan program aplikasi Geogebra dalam pembelajaran} matematika, khususnya materi lingkaran.

Setelah diperkenalkan dengan aplikasi Geogebra, siswa dijelaskan cara menggunakan program aplikasi ini untuk belajar matematika, khususnya materi lingkaran. Materi lingkaran dipilih karena siswa kelas VIII SMP yang menjadi objek sedang mempelajarinya. Selain itu, materi ini juga sangat baik diajarkan dengan bantuan Geogebra. Ini disebabkan lingkaran adalah bangun datar yang dapat digambar menggunakan fitur yang ada di Geogebra. Tentu hal tersebut dapat memudahkan guru maupun siswa untuk menggambar lingkaran sesuai dengan ukuran diameter atau jarijari yang diinginkan.

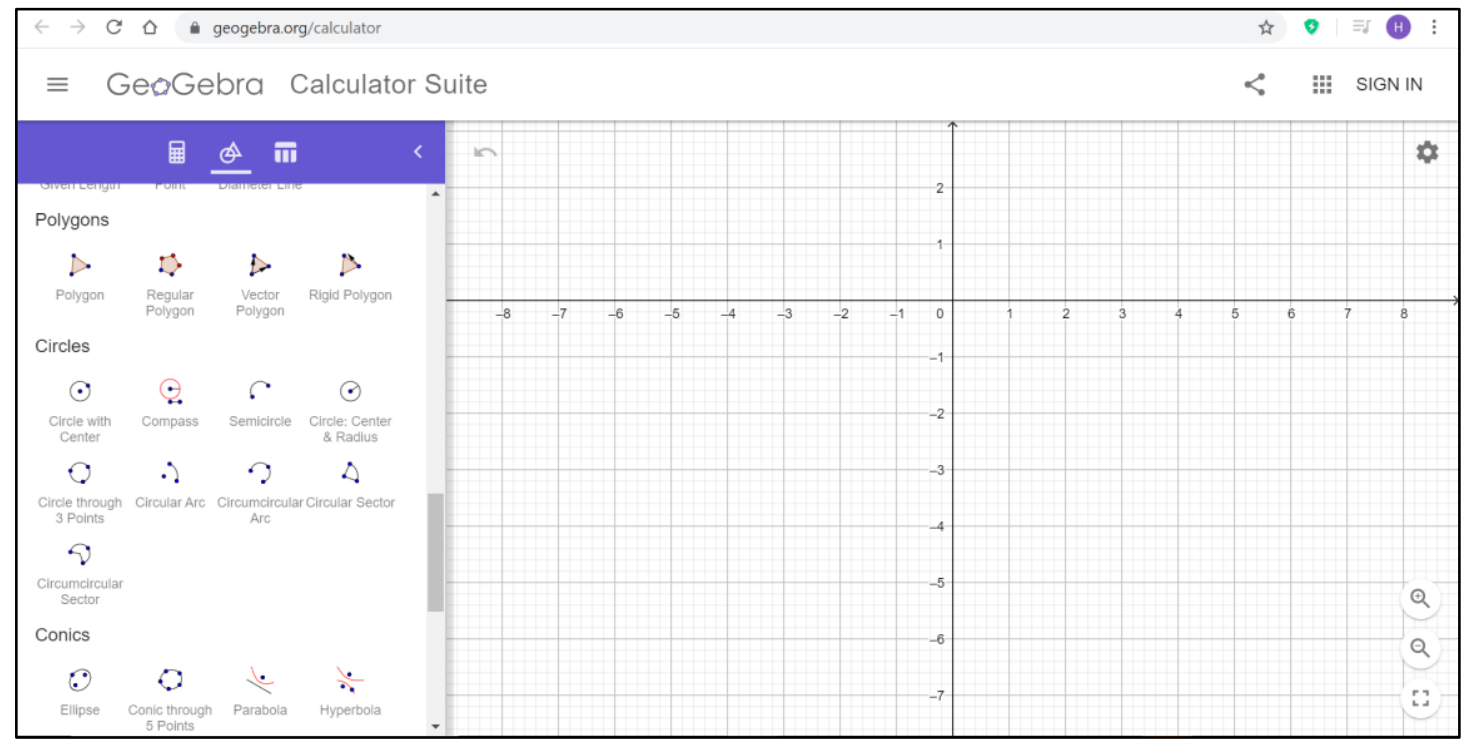

Gambar 4. Tampilan fitur Circles di Situs Geogebra versi Online

Gambar di atas menunjukkan fitur Circles yang ada di situs Geogebra versi Online. Siswa dapat memilih bentuk lingkaran yang ingin digambar pada bidang cartesius yang ada pada tampilan Geogebra. Berikut adalah fungsi ikon yang ada pada fitur Circles di Geogebra:

- Circle with Center through Point (Lingkaran dengan pusat melalui titik). Setelah pengguna melakukan pengklikan suatu titik $A$ dan suatu titik $O$, akan mendefinisikan suatu lingkaran dengan pusat A melalui O. Jari-jari lingkaran adalah berupa jarak AO.

- Circle with Center and Radius (Lingkaran dengan pusat dan jari-jari). Setelah membuat titik pusat $\mathrm{A}$, pengguna akan diminta memasukkan nilai jari-jari pada Bilah input pada kotak dialog yang muncul. 
- Compass (Jangka). Ketika pengguna membuat suatu segmen garis MP atau dua titik M dan P, akan mendefinisikan suatu jari-jari lingkaran. Selanjutnya, pengguna diminta mengklik satu kali lagi yang bertujuan untuk menentukan posisi titik pusat lingkaran.

- Circle through 3 Points (Lingkaran melalui tiga titik). Apabila pengguna membuat tiga titik $\mathrm{X}, \mathrm{Y}$, dan Z, akan mendefinisikan suatu lingkaran melalui ketiga titik tersebut. Jika ketiga titik ini terletak pada suatu garis lurus, maka terbentuklah lingkaran yang dihasilkan melalui garis ini.

- Semicircle through 2 Point (Setengah lingkaran dengan dua titik). Setelah membuat dua titik $\mathrm{P}$ dan $\mathrm{Q}$, pengguna akan menghasilkan suatu busur setengah lingkaran pada suatu ruas garis PQ.

- Circular Arc (Busur sirkular dengan pusat melalui dua titik). Apabila pengguna membuat tiga titik $\mathrm{X}, \mathrm{Y}$, dan $\mathrm{Z}$, akan menghasilkan suatu busur sirkular dengan pusat $\mathrm{X}$, berawal dari titik $\mathrm{Y}$ dan berakhir pada titik $\mathrm{Z}$ atau terletak pada ruas garis XZ. Catatan: Titik Z tidak harus selalu terletak pada busur tersebut.

- Circumcircular Arc (Busur melalui tiga titik). Jika pengguna membuat tiga titik, maka akan menghasilkan suatu busur yang melalui tiga titik tersebut.

- Circular Sector (Sektor sirkular dengan pusat melalui dua titik). Setelah pengguna membuat titik A, B, dan C, akan menghasilkan suatu sektor sirkular dengan pusat A, berawal dari titik B dan berakhir pada titik $\mathrm{C}$ atau terletak pada ruas garis AC. Catatan: Titik $\mathrm{C}$ tidak harus selalu terletak pada sektor tersebut.

- Circumcircular Sector (Sektor melalui tiga titik). Apabila pengguna membuat tiga titik, maka akan menghasilkan suatu sektor yang melalui tiga titik tersebut.

Setelah siswa memahami fungsi ikon tersebut, dimulailah penjelasan cara membuat lingkaran dan unsur-unsurnya menggunakan aplikasi Geogebra. Unsur-unsur lingkaran yang dijelaskan meliputi:

1) Titik Pusat Lingkaran merupakan titik yang berada tepat di tengah-tengah lingkaran sebagai pusatnya.

2) Jari-Jari Lingkaran adalah sebuah garis yang menghubungkan antara titik pusat dengan titik lengkung pada keliling lingkaran. Umumnya jari-jari lingkaran ini disimbolkan dengan simbol $r$.

3) Diameter Lingkaran merupakan sebuah garis panjang lurus yang menghubungkan antara dua titik pada keliling lingkaran yang melewati titik pusat lingkatran. Dapat disimpulkan kalau panjang diameter adalah 2 kali lipat panjang jari-jari lingkaran. Diameter lingkaran disimbolkan dengan $d$ atau $D$. 
4) Tali Busur Lingkaran adalah tali busur lingkaran adalah garis lurus yang menghubungkan dua titik pada keliling lingkaran, tapi tidak melalui titik pusat lingkaran. Hal ini agak berbeda dengan diameter yang garisnya melalui titik pusat.

5) Juring lingkaran adalah luas daerah dalam lingkaran yang dibatasi oleh dua garis jari-jari dan dibatasi oleh sebuah busur lingkaran yang letaknya diapit oleh dua buah jari-jari tersebut. Juring lingkaran juga dibagi jadi dua, yaitu juring kecil dan juring besar.

6) Tembereng Lingkaran adalah luas daerah yang berada di dalam lingkaran yang dibatasi oleh busur dan tali busur lingkaran.

7) Apotema Lingkaran yaitu jarak terpendek antara tali busur dengan titik pusat lingkaran. Garis apotema umumnya berada tegak lurus dengan tali busur.

8) Busur Lingkaran adalah garis lengkung yang merupakan bagian dari keliling lingkaran. Busur pada lingkaran dibagi jadi dua, yaitu busur besar dan busur kecil. Disebut sebagai busur besar jika panjangnya lebih dari setengah lingkaran, sedangkan busur kecil jika panjangnya kurang daru setengah lingkaran.

9) Sudut Pusat Lingkaran yaitu sebuah sudut yang terbentuk dari potongan antara dua buah jari-jari yang ada di titik pusat lingkaran.

10) Sudut Keliling adalah sebuah sudut yang terbentuk karena pertemuan antara dua tali busur dengan satu titik pada keliling lingkaran.

Semua unsur tersebut dijelaskan kepada siswa dengan menggambarkannya di aplikasi Geogebra. Siswa sangat antusias melihat cara pembuatan lingkaran dan unsur-unsurnya. Lingkaran beserta unsur-unsurnya dibuat sangat mudah dan tergambar dengan jelas sehingga para siswa memahami detail unsurnya.

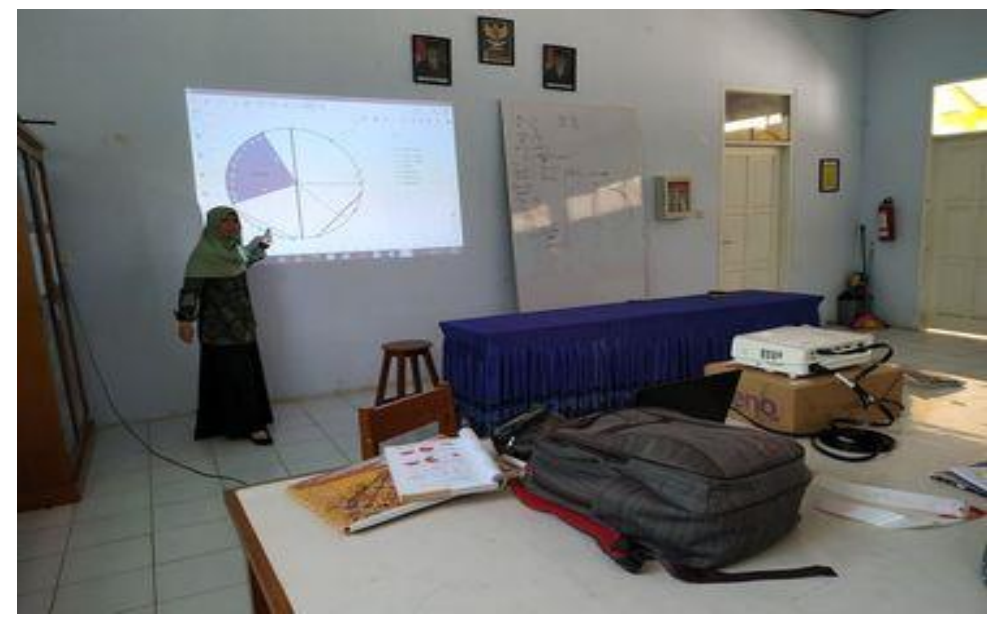

Gambar 5. Proses Penjelasan untuk Menggunakan Aplikasi Geogebra 


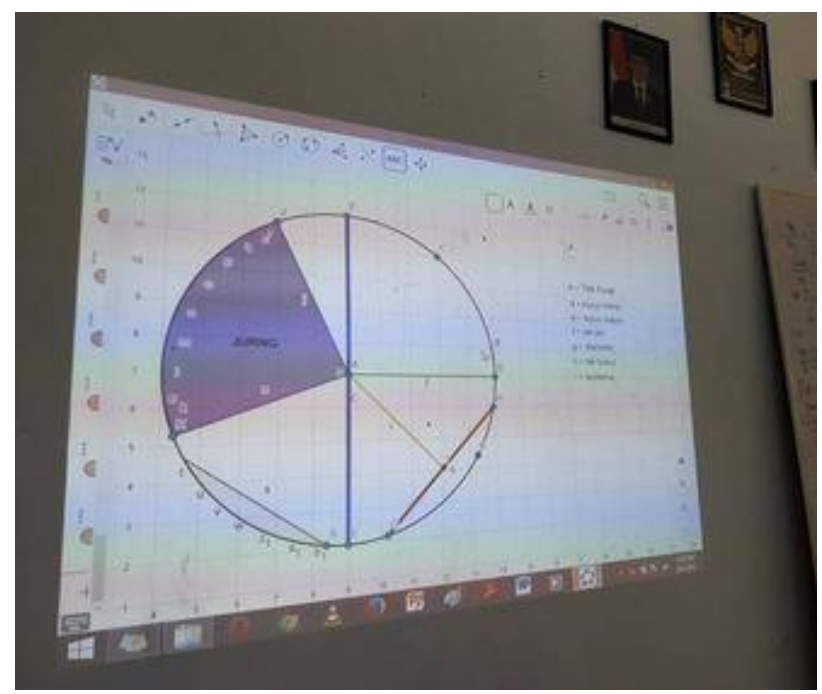

\section{Gambar 6. Unsur-unsur Lingkaran yang tergambar pada Aplikasi Geogebra}

3. Simulasi penggunaan program aplikasi Geogebra pada materi lingkaran.

Setelah dijelaskan cara membuat lingkaran dan unsur-unsurnya menggunakan Geogebra, siswa melakukan simulasi penggunaan program aplikasi Geogebra di Smartphone. Beberapa siswa ada yang langsung mengunduh aplikasi tersebut di Play Store, namun ada juga siswa yang menggunakan Geogebra versi Online untuk membuat lingkaran dan unsur-unsurnya.
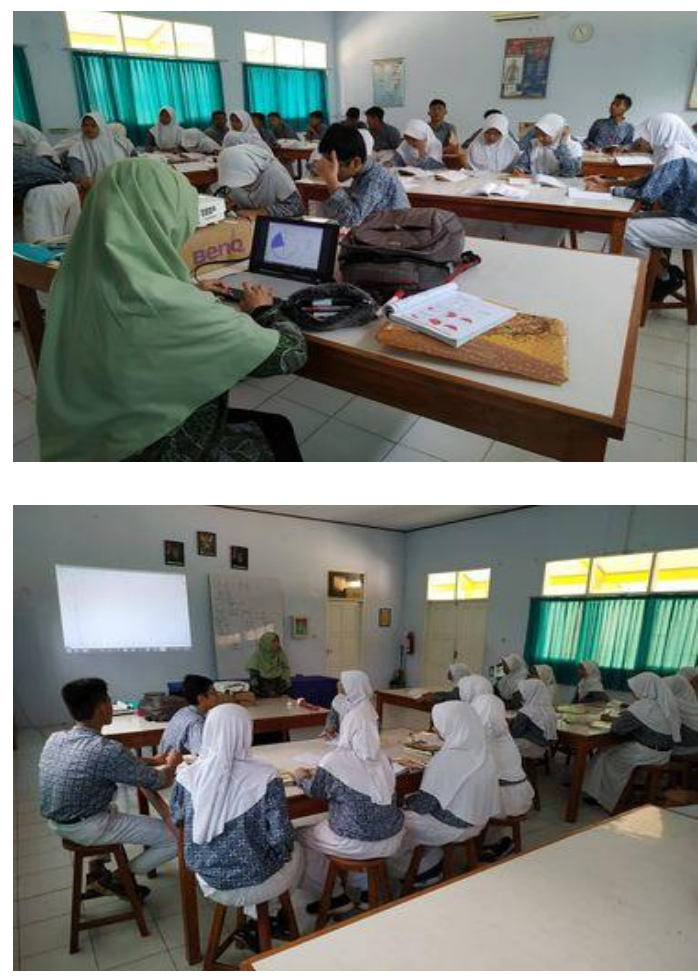

Gambar 7. Siswa Fokus dalam Simulasi Penggunaan Aplikasi Geogebra 


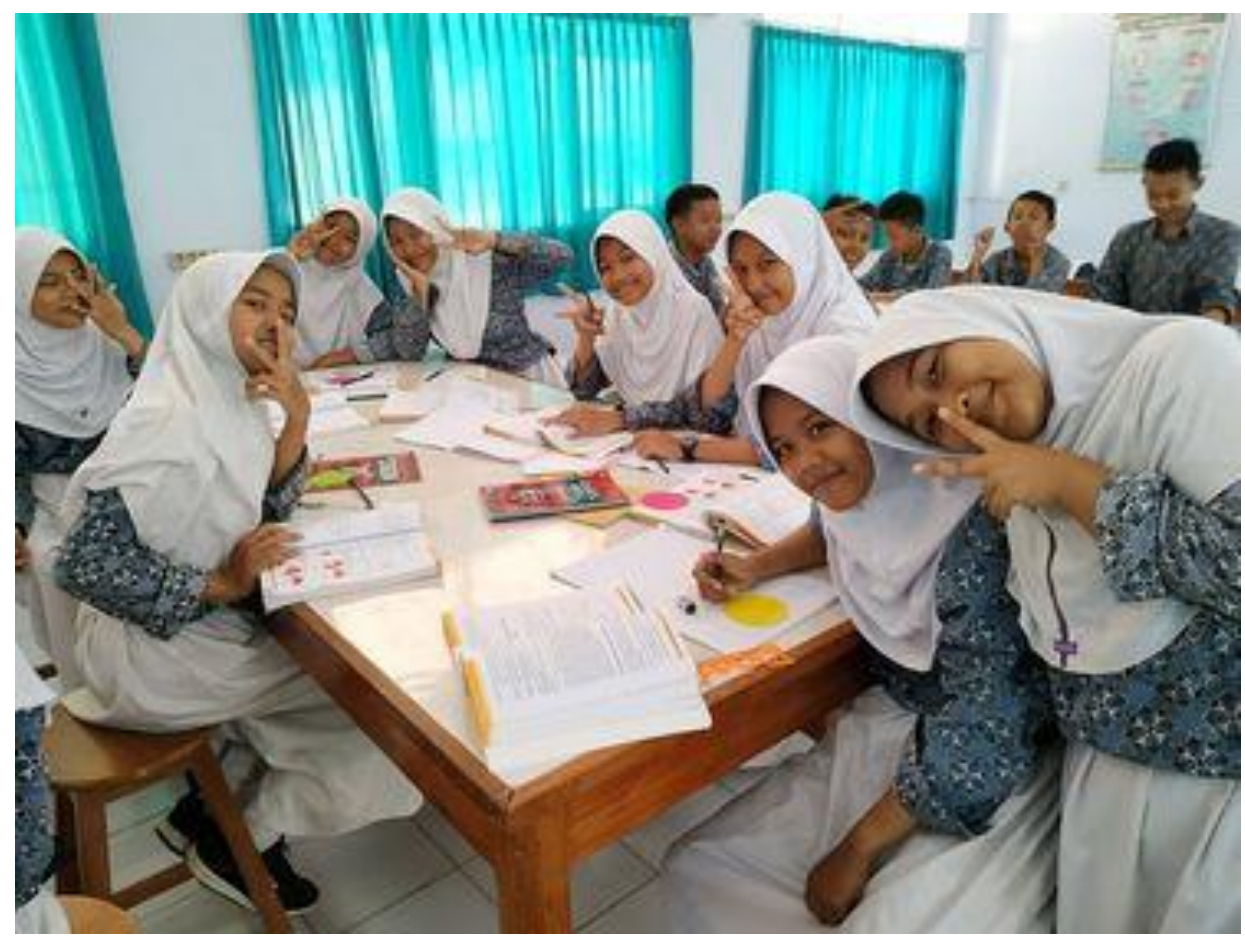

\section{Gambar 8. Antusiasme Siswa dalam Pembelajaran Matematika} Menggunakan Aplikasi Geogebra

Siswa terlihat antusiasme dalam pembelajaran menggunakan Geogebra ini. Ketika dilakukan proses wawancara saat proses simulasi berlangsung, beberapa siswa menyatakan kegembiraannya dapat mengenal aplikasi tersebut. Ada juga siswa yang tertarik menggunakannya untuk materi yang terkait bangun ruang. Bangun ruang merupakan salah satu materi yang menurutnya sulit untuk digambar secara manual sehingga butuh aplikasi seperti ini.

Kegiatan terakhir adalah menentukan siswa yang dianggap paling ahli dalam menggunakan aplikasi tersebut. Penulis memberikan latihan soal yang membuat siswa harus segera menyelesaikannya pada Geogebra. Sampai akhirnya, muncullah dua siswa terbaik yang merupakan siswa tercepat dalam menyelesaikan latihan soal itu. Dua siswa tersebut diminta untuk maju ke depan kelas untuk menerima penghargaan dari penulis sebagai bentuk apresiasi atas keahliannya dalam menggunakan aplikasi Geogebra. 


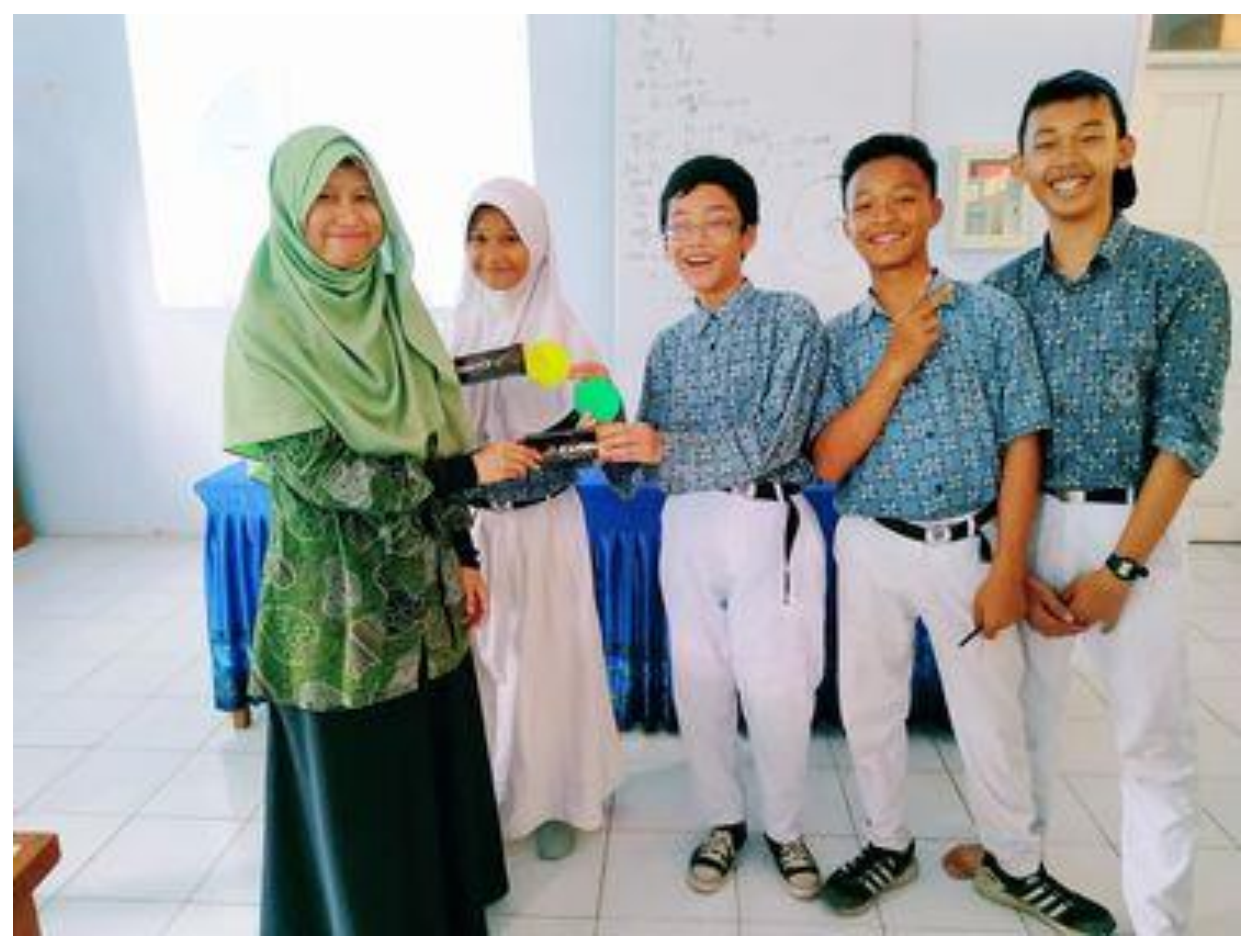

Gambar 9. Penghargaan kepada siswa yang ahli dalam Penggunaan Aplikasi Geogebra

\section{KESIMPULAN}

Setelah dilaksanakan kegiatan pelatihan penggunaan aplikasi geogebra pada pembelajaran materi lingkaran pada siswa kelas VIII di SMP 10 Kota Serang, siswa memahami dan mengenal aplikasi tersebut. Siswa juga menjadi ahli dalam membuat lingkaran dan unsur-unsurnya pada aplikasi Geogebra. Dengan menjadi ahli dalam penggunaan aplikasi Geogebra, diharapkan siswa dapat memahami materi lingkaran lebih dalam dan juga materi selanjutnya yang berkaitan dengan materi yang sedang dipelajari.

\section{UCAPAN TERIMA KASIH}

Ucapan terimakasih disampaikan kepada

1. Ibu Nur Hidayanti, M.Pd selaku Kepala LPPM Universitas Banten Jaya yang telah mendukung kegiatan Pengabdian Kepada Masyarakat ini.

2. Ibu Dr. Meti Ismurti, M.Pd selaku Kepala SMP Negeri 10 Kota Serang yang telah mengizinkan SMP Negeri 10 Kota Serang sebagai mitra pengabdian.

3. Bapak Maulfi Kharis Abadi, M.Pd selaku Guru Matematika di SMP Negeri 10 Kota Serang yang sudah menjadi teman diskusi dalam kegiatan PKM ini.

4. Seluruh siswa kelas VIII C SMP Negeri 10 Kota Serang yang sangat antusias untuk belajar bersama. 


\section{DAFTAR PUSTAKA}

Agung, S., Ma'rufi, M., \& Ilyas, M. (2019). Pengembangan Perangkat Pembelajaran Berbasis Media Aplikasi Geogebra Pada Materi Geometri Untuk Meningkatkan Higher Order Thinking Skills Siswa. MaPan, 7(2), 194-210. https://doi.org/10.24252/mapan.2019v7n2a3

Hasanah, H. (2020). Pengembangan Bahan Ajar Matematika Berbasis STEM Pada Materi Bangun Ruang. Indonesian Journal of Learning Education and Counseling, 3(1), 91-100. https://doi.org/10.31960/ijolec.v3i1.582

M.Nur, I. (2016). Pemanfaatan Program Geogebra Dalam Pembelajaran Matematika. Jurnal Matematika Dan Pendidikan Matematika, 5(1), 10-19.

Mahmudi, A. (2010). Membelajarkan Geometri dengan Program GeoGebra. Prosiding Seminar Nasional Matematika Dan Pendidikan Matematika, November, 469-477.

Nasional, U. S. P. (2003). Undang-undang sistem pendidikan nasional.

Rismawati, Hayati, R., \& Khatimah, H. (2020). Penerapan Aplikasi Geogebra untuk Meningkatkan Hasil Belajar Siswa pada Materi Matriks. Serambi Akademica: Jurnal Pendidikan, Sains, Dan Humaniora, 8(2), 210-215.

Septian, A. (2017). Penerapan Geogebra Untuk Meningkatkan Kemampuan Pemecahan Masalah Matematis Mahasiswa Program Studi Pendidikan Matematika Universitas Suryakancana. Prisma, 6(2), 180-191. https://doi.org/10.35194/jp.v6i2.212

Susanah Pradnyo Wijayanti, Rini setianingsih, S. F. (2018). Pelatihan Penggunaan Aplikasi Geogebra. ABDI, 3(2), 46-51.

Tanzimah. (2019). Pemanfaatan Software Geogebra dalam Pembelajaran Matematika. Prosiding Seminar Nasional Pendidikan Program Pascasarjana Universitas PGRI Palembang, 610-616. https://doi.org/10.19109/jpmrafa.v3i1.1441

Ucu Koswara, Tuti Yuliawati W, dan N. T. R. (2017). Pelatihan Prohgram Geogebra bagi Guru Matematika SMP di Kabupaten Sumedang. E-Dimas, 8(1), 77-86. 